\title{
On the Relationship between Credit Rating Announcements and Credit Default Swap Spreads for European Reference Entities
}

\author{
Thorsten Lehnert * \\ Limburg Institute of Financial Economics (LIFE), Maastricht University, \\ P.O. Box 616, 6200 MD Maastricht, The Netherlands \\ Frederick Neske \\ Faculty of Economics and Business Administration, Maastricht University, \\ P.O. Box 616, 6200 MD Maastricht, The Netherlands
}

This version: March, 2004

\begin{abstract}
Previous research suggests that credit rating announcements by Moody's are anticipated by participants in the credit default swap market. In particular, it is argued that downgrades and negative outlook reports do not contain significant information, but there seems to be anticipation of both types of ratings announcements. In this paper, we examine credit default swap spread changes conditional on a ratings announcement for European reference entities. For our sample of J.P. Morgan Trak-X Europe companies, we find evidence that downgrades and negative outlooks do contain significant information, but find no evidence that announcements are anticipated by participants in the credit default swap market. Additionally, we find evidence that CDS spreads initially do not fully adjust to the information in positive or stable outlook reports resulting in significant post-announcement day effects.
\end{abstract}

Keywords: Credit default swap, CDS spread, rating announcements.

* Correspondence to: Tel: +31-43-3883838; Fax: +31-43-3884875. E-mail: t.lehnert@,berfin.unimaas.nl. We are grateful to J.P. Morgan Securities Ltd., London, for making their data on CDS spreads available to us. We also would like to thank Marcus Schüler, Robert Grossman and Bart Frijns for useful comments and suggestions. 


\section{Introduction}

Credit derivatives are bilateral contracts that stipulate a payment from one party to another in case a so-called credit event, such as default, occurs. The potential payer is compensated with a fee, the credit spread. Credit derivatives have been first introduced in the United States at the beginning of the 1990s, however, the European credit derivative market has followed suit and its emergence is forecasted to affect the mode that European companies deal with credit risk and raise capital. Analysts believe that European corporations will transform their historically loan-based funding into a more capital market oriented mode of raising capital. Credit derivatives have also affected the attitude that investors, primarily banks, have towards their position. Whereas in the past, European banks, especially German banks, used to pursue a "buy-and-hold" strategy, they now increasingly changed to an "underwriting-and-distribution" approach. Banks do not longer hold their positions until they mature but rather trade them in secondary markets. Managing the related credit risk is therefore very important and the emergence of credit derivatives has facilitated this transformation of the stance that market participants have towards their investments. Credit derivatives exist in a wide variety of forms, yet credit default swaps (CDS) represent the largest segment of this market. This relatively new financial instrument can be defined as a contract between two counterparties, in which one party, the protection seller agrees to make a payment to the protection buyer conditional on a credit event in exchange for a predetermined fee. There is no payment made to the protection buyer in absence of a credit event. The protection seller has no obligation if no credit event occurs. The credit event is commonly related to an asset that is held by the protection buyer.

Previous research has extensively investigated the relationship between credit rating changes and bond or stock price changes. However, the empirical evidence regarding anticipation of different types of rating announcements by the market is mixed. In one of the first studies, Katz (1974) looks at the reaction of bond prices to rating reclassifications. He finds evidence for anticipation before decreases. Wansley et al. (1992) and more recently Dynkin et al. (2002) confirm that bond prices decrease during the period before and after the announcement of a downgrade. In a recent study, Steiner and Hanke (2001) conclude that negative reviews and downgrades result in negative bond returns after the announcement, but find no effects for positive reviews and upgrades. In general, empirical 
studies that have looked at the relationship between stock returns and credit ratings find similar results (e.g Hand et al. (1992), Goh and Ederington (1993) and Goh and Ederington (1999)). In particular, Pinches and Singleton (1978) and Holthausen and Leftwich (1986) find evidence for the anticipation hypothesis of rating announcements. In a very recent study, Hull et al. (2004) find that credit rating announcements by Moody's are anticipated by participants in the credit default swap market. In particular, downgrades and negative outlook reports do not contain significant information, but there seems to be anticipation of both types of ratings announcements.

In this paper, we investigate the affect of credit rating related information on the spread levels of credit default swaps in European capital markets. Credit rating actions will be extensively analyzed according to the type of rating announcement, the risk category and the degree of credit rating action. Moreover, the spread will be analyzed conditionally to previous information on the rating and whether a rating action alters the risk category of the underlying reference entity. The remainder of the paper is arranged as follows. The following Section discusses the data. In Section 3, we conduct empirical tests and provide the empirical results. Finally, Section 4 concludes.

\section{Data}

As a research sample, all reference entities included in the TRAC-X Europe index of J.P. Morgan were chosen ${ }^{1}$. It is the successor of J.P. Morgan's JECI and Morgan Stanley's synthetic EURO Tracers (J.P. Morgan (2003)). It offers investors a diverse and liquid vehicle for managing exposure to the European credit market. TRAC-X Europe is comprised of 100 major companies from virtually all business sectors. All reference entities included in the index are weighted equally in order to facilitate a simpler and more transparent product. The composition is based on liquid credit default swaps rather than liquid cash bonds to assure an optimal exposure to the credit market. All corporations are of investment grade according to definitions by both Standard \& Poor's and Moody's, which means they are rated BBB-/Baa3 or higher. All 100 reference entities that were included in our sample are listed in Table 1.

\footnotetext{
${ }^{1}$ Recently this index has been sold to the NYSE and is now called Dow-Jones Trac-X Europe 99.
} 
[Table 1]

As variable of interest, the credit default swap spread of the TRAC-X companies was chosen. We use market data supplied by J.P. Morgan, one of the leading players in the CDS market. Concerning the maturity of the CDS contracts, we used the most popular five-year term contracts. The CDS quotes used in the sample were all for senior unsecured debt issued by the reference entities. Daily CDS quotes were used in the analysis ranging from August 2000 until August 2003. The credit default swap spread is in basis points and the currency underlying the CDS contracts is the Euro.

Information concerning the performance and financial strength of companies is released on a frequent basis. Over the past years, the importance of assessing the financial strength and creditworthiness of a company increased dramatically, especially in Europe. Rating agencies release a great variety of information, among others credit ratings that measure the faith concerning the ability to repay debt. In our study, we examine information released by the rating agency Moody's concerning the creditworthiness of the sample companies and its effect on CDS spreads. All data concerning the rating actions was extracted from the Moody's website and from Bloomberg's credit profiler. In general, it can be differentiated between two types of events, mainly positive ones and negative ones. Positive events are classified as upgrades, positive outlook reports and stable outlook reports $^{2}$. Negative events are downgrades and negative outlook reports. In total 188 events could be observed during the 3 years time period. The distribution of events was somewhat biased towards negative announcements concerning the creditworthiness of sample companies. 70 negative outlook reports were observed along with 57 actual downgrades being issued. Positive events are comprised of 51 positive/stable outlook reports and 10 upgrades actually taking place.

Downgrades were analyzed more thoroughly. At first, the degree of downgrade was differentiated. Events were defined as 1-notch downgrades and 2/3-notch downgrades ${ }^{3}$. We are interested in the relationship between the intensity of a downgrade and the change in the

\footnotetext{
${ }^{2}$ In our analysis, stable outlook reports are combined with positive outlook reports in one category, since positive outlook reports across the sample period were quite infrequent, which might be due to the relatively moderate economic growth in Europe for the sample period.
} 
CDS spread. Moreover, events were distinguished according to whether a category dismissal occurred with the announcement. This means that a downgrade moved a reference entity to a lower credit risk class. A 1-notch downgrade from A3 to Baa1 would be an example of such a category dismissal. Furthermore, it was analyzed whether the CDS spread change would be different depending on whether a negative outlook report had been published before the actual downgrade.

\section{Empirical Tests}

In our analysis, events are defined as rating actions by Moody's and the impact variable is the CDS spread of the sample reference entities. At first, the time around an event was divided into two time periods, one control period and one event period. We assumed the control period to be 60 business days. It ranges from day 70 until day 11 before the actual event occurs. The control period was chosen to explicitly examine and compare the actual impact of the announcement on the CDS spread around the announcement period. Next, the event period had to be defined. We would like to examine the effect before and after an actual announcement had taken place. Therefore, three event periods were defined. The first event period is the pre-period and it lasts from 10 days to one day before the credit rating action. The second event period is the post-period, which lasts from one day to ten days after the announcement. The particular choice of the event period was motivated by previous studies. For example, results by Steiner and Heinke (2001) suggest that the period right before and after the announcements was the most informative one. Finally, the day on which the news hit the market was examined by comparing the return over the control period and the return on the announcement day.

In order to make the change in the spread comparable across risk classes and across different rating actions, the percentage changes of the individual company's CDS spreads were calculated for all days covering the time frame of the study. In a next step, we adjust the spread by subtracting the average daily percentage change of CDS spreads within a particular investment grade category. Doing this has the advantage to eliminate for extraordinary changes in CDS spreads that affect all companies in the sample in the same

\footnotetext{
${ }^{3}$ A one-notch downgrade is a declassification of one point, i.e. from Baa1 to Baa2. Accordingly, a two-notch downgrade is a decline by 2 points, i.e. to Baa3.
} 
way. Sometimes, macroeconomic events occur that disrupt capital and credit markets. The terror attacks of $11^{\text {th }}$ September or interest rate shifts are examples of such news or events that affect the CDS spreads of all reference entities.

Table 2 presents the results for spread changes conditional on rating events. The Table reports the average change in the adjusted CDS spread during the pre-/postannouncement period or on the event day. It is indicated if the mean change in the adjusted CDS spread over a particular announcement period significantly differs from the mean change over the control period. Since the number of upgrades over the whole sample period was relatively small (10 upgrades in total), the (insignificant) results for upgrades are not reported.

[Table 2]

The release of information concerning the creditworthiness of a company does certainly influence the CDS spread. A negative (positive/stable) outlook report does lead to an increase (decrease) in the credit default swap spread. The results are significant at the $1 \%$ or $5 \%$ confidence level, respectively. Therefore, we do not find an asymmetry in the market's reaction to positive and negative announcements, but confirm previous findings regarding the information content in rating changes. However, we find different announcement effects that are in contrast to Hull et al. (2004). First, our results suggest that the actual downgrade still contains significant information. Second, the different types of announcements are not anticipated by the market. Third, the market seems to underreact only to positive news and as a result, we find a significant post-announcement effect for positive or stable outlook reports. On the announcement day, only the negative news is fully incorporated in the spread, but it takes some days until the CDS spread fully adjusts to positive news. This asymmetry in the CDS market's reaction has not documented before.

[Table 3] 
Table 3 reports individual results for the particular rating categories. Regarding negative events, we find that a negative outlook report has the largest impact on the CDS spread for companies in the category Aaa/Aa or A. On the other hand, the effect of a downgrade is most significant for a Baa rated company, most likely because of a possible category dismissal below an investment grade. It is always surprising that the percentage change for negative outlook reports is larger than that of downgrades. Intuitively, one would suggest that a downgrade represents a stronger concern about the creditworthiness of a reference entity than a negative outlook report. A possible explanation could be that downgrades are often preceded by negative outlook reports and that credit analysts incorporate a possible future downgrade in the price adjustments for negative outlook reports.

Our results suggest that the actual downgrade contains significant information beyond the information content in negative outlook reports. Therefore, we further investigate the announcement day effects of all downgrades, differentiating between 1notch downgrades and 2-notch downgrades, category dismissals and downgrades that were preceded by negative outlook reports. To the best of our knowledge, ours is the first research to conduct those additional tests on CDS spreads. Table 4 reports the differences in the mean adjusted spreads for the additional tests.

[Table 4]

The effects of a 2-notch downgrade are obviously much stronger than the effect of 1-notch downgrades. On average the impact of a 2-notch downgrade on the CDS spread is highly significant and more than 6 times higher than the one for 1-notch downgrades. A category dismissal is defined as a downgrade that results in a shift concerning the rating class for the respective reference entity. Across the whole sample of 57 observations, we find 26 downgrades that resulted in a category dismissal. The mean adjusted CDS spread changes of those 26 downgrades are significantly different and on average $4 \%$ larger than the ones that resulted in no category dismissal. This result is in line with earlier studies like Hite and Warga (1997) on bond returns or Goh and Ederington (1999) on stock returns. Finally, we couldn't find significant differences in mean CDS changes on the announcement day between companies that experienced a negative outlook report during the control period 
compared to others. This was done to examine whether the announcement effect for reference entities that experienced no warning right before the actual downgrade was announced, had a stronger effect than companies that were not subjected to this kind of event. Interestingly, this result suggests that both negative events, the negative outlook report and the actual downgrade, are considered independent events by the market.

\section{Conclusions}

In this paper, we investigate the affect of credit rating related information on the spread levels of credit default swaps for European reference entities. The empirical results of Hull et al. (2004) suggest that credit rating announcements by Moody's are anticipated by participants in the credit default swap market and downgrades and negative outlook reports do not contain significant information. Our findings are questioning those results and are more in line with other previous research, which considered bond and stock price reactions to rating changes. The release of information concerning the creditworthiness of a company does certainly influence the CDS spread. A negative (positive/stable) outlook report does lead to a significant increase (decrease) in the credit default swap spread. However, we find different announcement effects: First, our results suggest that the actual downgrade still contains significant information. Second, the different types of announcements are not anticipated by the market. Third, we find a significant post-announcement effect for positive or stable outlook reports. Fourth, the impact of a 2-notch downgrade or a category dismissal on the CDS spread is very pronounced. Fifth, negative outlook reports and the actual downgrades are considered independent events by the market. The differences may be partly due to the relative youth of the European market for credit default swaps. 


\section{References}

Dynkin, L., J. Hyman, and V. Konstantinovsky, (2002), "Sufficient Diversification in Credit Portfolios", Journal of Portfolio Management, Fall, 89-114.

Goh, J.C. and L.H. Ederington (1993), "Is a Bond Rating Downgrade Bad News, Good News, or No News for Stockholders?” Journal of Finance, 48, 2001-2008.

Goh, J.C. and L.H. Ederington, (1999), "Cross-Sectional Variation in the Stock Market Reaction to Bond Rating Changes" Quarterly Review of Economics and Finance, 39, 101-112.

Hand, J., R.W. Holthausen and R.W. Leftwich (1992), “The Effect of Bond Rating Agency Announcements on Bond and Stock Prices”, Journal of Finance, 47, 733-752.

Hite, G. and A. Warga (1997), "The Effect of Bond-Rating Changes on Bond Price Performance”, Financial Analysts Journal, May/June, 35-51.

Holthausen, R.W. and R.W. Leftwich, (1986) "The Effect of Bond Rating Changes on Common Stock Prices", Journal of Financial Economics, 17, 57-89.

Hull, John, Predescu, Mirela, White, Alan (2004), "The relationship between credit default swap spreads, bond yields, and credit rating announcements", forthcoming: Journal of Banking and Finance.

J.P. Morgan (2003), "Introducing TRAC-X Europe, the next generation of credit indices", J.P. Morgan Securities Ltd. London, UK.

Katz, S. (1974), “The Price and Adjustment Process of Bonds to Rating Reclassifications: A Test of Bond Market Efficiency", Journal of Finance, 29, 551-559.

Pinches, G.E. and J.C. Singleton, (1978), "The Adjustment of Stock Prices to Bond Rating Changes", Journal of Finance, 33, 29-44.

Steiner, M. and V.G. Heinke, (2001) "Event Study Concerning International Bond Price Effects of Credit Rating Actions" International Journal of Finance and Economics, 6, 139-157.

Wansley, J.W., J.L. Glascock and T.M. Clauretie, (1992), "Institutional Bond Pricing and Information Arrival: The Case of Bond Rating Changes" Journal of Business Finance \& Accounting, 19, 733-750. 
Table 1

TRAC-X Europe composition

\begin{tabular}{|c|c|c|}
\hline Company & Country & Industry \\
\hline Abbey National plc & United King dom & Financial Services/Bank \\
\hline ABN AMRO Bank NV & The Netherlands & Financial Services/Bank \\
\hline Accor & France & Non-Cyclical Consumer Goods \\
\hline Adecco SA & Switzerland & Non-Cyclical Consumer Goods \\
\hline Allianz AG & Germany & Financial Services/Bank \\
\hline Arcelor Finance SCA & Luxemburg & Basic Industry \\
\hline AXA & France & Financial Services/ Bank \\
\hline BAA plc & United King dom & Utility \\
\hline BAE Systems plc & United King dom & Capital Goods \\
\hline Banca Intesa Spa & Italy & Financial Services/ Bank \\
\hline Banco Bilbao Vizcaya Argentaria SA & Spain & Financial Services/ Bank \\
\hline Banco Comercial Portugues SA & Portugal & Financial Services/Bank \\
\hline Banco Espirito Santo S.A. & Portugal & Financial Services/ Bank \\
\hline Banco Santander Central Hispano SA & Spain & Financial Services/ Bank \\
\hline Bank of Scotland & United King dom & Financial Services/ Bank \\
\hline Barclays Bank plc & United Kingdom & Financial Services/ Bank \\
\hline Bayer AG & Germany & Basic Industry \\
\hline Bayerische Hypo Und Vereinsbank AG & Germany & Financial Services/ Bank \\
\hline Bayerische Motoren Werke AG & Germany & Non-Cyclical Consumer Goods \\
\hline Bertelsmann AG & Germany & Media\&T elecoms \\
\hline Boots Group plc & United King dom & Non-Cyclical Consumer Goods \\
\hline British American Tobacco plc & United King dom & Cyclical Consumer Goods \\
\hline British Telecommunications plc & United King dom & Media\&T elecoms \\
\hline Cadbury Schweppes plc & United Kingdom & Cyclical Consumer Goods \\
\hline Carlton Communications plc & United King dom & Media\&T ele coms \\
\hline Carrefour SA & France & Cyclical Consumer Goods \\
\hline Casino Guichard Perrachon & France & Cyclical Consumer Goods \\
\hline Commerzbank AG & Germany & Financial Services/ Bank \\
\hline Compagnie de Saint-Gobain & France & Basic Industry \\
\hline Continental AG & Germany & Non-Cyclical Consumer Goods \\
\hline Credit Lyonnais SA & France & Financial Services/ Bank \\
\hline Credit Suisse Group & Switzerland & Financial Services/ Bank \\
\hline DaimlerChrysler $A G$ & Germany & Non-Cyclical Consumer Goods \\
\hline Deutsche Bank AG & Germany & Financial Services/ Bank \\
\hline Deutsche Lufthansa AG & Germany & Transport \\
\hline Deutsche Telekom AG & Germany & Media\&Telecoms \\
\hline Dixons Group plc & United King dom & Non-Cyclical Consumer Goods \\
\hline Dresdner Bank AG & Germany & Financial Services/ Bank \\
\hline DSMNV & The Netherlands & Basic Industry \\
\hline E.On AG & Germany & Utility \\
\hline EDP-Electricidade de Portugal SA & Portugal & Utility \\
\hline Electricite de France Service National & France & Utility \\
\hline Endesa SA & Spain & Energy \\
\hline Enel SpA & Italy & Utility \\
\hline Finmeccanica SpA & Italy & Capital Goods \\
\hline France Telecom & France & Media\&T elecoms \\
\hline GUS plc & United Kingdom & Non-Cyclical Consumer Goods \\
\hline Hellenic Telecommunications & Greece & Media\&Telecoms \\
\hline Hilton Group plc & United Kingdom & Non-Cyclical Consumer Goods \\
\hline
\end{tabular}




\section{TRAC-X Europe composition continued}

\begin{tabular}{|c|c|c|}
\hline Company & Country & Industry \\
\hline HSBC Bank plc & United Kingdom & Financial Services/Bank \\
\hline Iberdrola SA & Spain & Utility \\
\hline Imperial Chemical Industries plc & United Kingdom & Basic Industries \\
\hline Imperial Tobacco Group plc & United Kingdom & Cyclical Consumer Goods \\
\hline ING Bank NV & The Netherlands & Financial Services/Bank \\
\hline Investor AB & Sweden & Capital Goods \\
\hline Koninklijke KPN NV & The Netherlands & Media\&Telecoms \\
\hline Koninklijke Philips Electronics NV & The Netherlands & Non-Cyclical Consumer Goods \\
\hline Lafarge & France & Basic Industries \\
\hline Lloyds TSB Bank plc & United Kingdom & Financial Services/Bank \\
\hline LVMH Moet Hennessy Louis Vuitton & France & Cyclical Consumer Goods \\
\hline Metro $A G$ & Germany & Cyclical Consumer Goods \\
\hline MMO2 plc & United Kingdom & Media\&Telecoms \\
\hline Nestle SA & Switzerland & Cyclical Consumer Goods \\
\hline Nokia Oyj & Finland & Technology \\
\hline Olivetti SpA & Italy & Media\&Telecoms \\
\hline Parmalat SpA & Italy & Cyclical Consumer Goods \\
\hline Pearson plc & United Kingdom & Media\&Telecoms \\
\hline Peugeot SA & France & Non-Cyclical Consumer Goods \\
\hline Portugal Telecom International Finance BV & Portugal & Media\&Telecoms \\
\hline Reed Elsevier plc & United Kingdom & Media\&Telecoms \\
\hline Renault SA & France & Non-Cyclical Consumer Goods \\
\hline Repsol YPF SA & Spain & Energy \\
\hline Reuters Group plc & United Kingdom & Media\&Telecoms \\
\hline Rolls-Royce plc & United Kingdom & Capital Goods \\
\hline Royal Bank of Scotland plc & United Kingdom & Financial Services/Bank \\
\hline RWE AG & Germany & Utility \\
\hline San Paolo IMI SpA & Italy & Financial Services/Bank \\
\hline Siemens AG & Germany & Capital Goods \\
\hline Societe Generale & France & Financial Services/Bank \\
\hline Sonera Oyj & Finland & Media\&Telecoms \\
\hline Standard Chartered Bank & United Kingdom & Financial Sewices/Bank \\
\hline STMicroelectronics NV & The Netherlands & Media\&Telecoms \\
\hline Suez & France & Utility \\
\hline TDC AVS & Denmark & Media\&Telecoms \\
\hline Telecom Italia SpA & Italy & Media\&Telecoms \\
\hline Telefonica SA & Spain & Media\&Telecoms \\
\hline TeliaSonera AB & Sweden & Media\&Telecoms \\
\hline Thomson & France & Non-Cyclical Consumer Goods \\
\hline UBSAG & Switzerland & Financial Services/Bank \\
\hline Unilever NV & The Netherlands & Cyclical Consumer Goods \\
\hline United Business Media plc & United Kingdom & Media\&Telecoms \\
\hline Valeo SA & Italy & Non-Cyclical Consumer Goods \\
\hline Vattenfall AB & Sweden & Utility \\
\hline Veolia Environnement & France & Utility \\
\hline VNU NV & The Netherlands & Media\&Telecoms \\
\hline Vodafone Group plc & United Kingdom & Media\&Telecoms \\
\hline Volkswagen $\mathrm{AG}$ & Germany & Non-Cyclical Consumer Goods \\
\hline Volvo $\mathrm{AB}$ & Sweden & Capital Goods \\
\hline Wolters Kluwer NV & The Netherlands & Media\&Telecoms \\
\hline WPP Group plc & United Kingdom & Media\&Telecoms \\
\hline
\end{tabular}




\section{Table 2}

The Table reports the mean change in the adjusted CDS spreads over the announcement period for the different rating actions. The time intervals $[-10,-1],[-1,1]$ and $[1,10]$ refer to the pre-announcement period, the event day and the post-announcement period, respectively. "No. of Events" refers to the number of observations within each category. ${ }^{*}$ and $* *$ indicate that the adjusted CDS spread changes are different at the $5 \%$ and $1 \%$ confidence level, respectively.

Announcement Period

\begin{tabular}{llll}
\hline No. of & {$[-10,-1]$} & {$[-1,1]$} & {$[1,10]$} \\
Events &
\end{tabular}

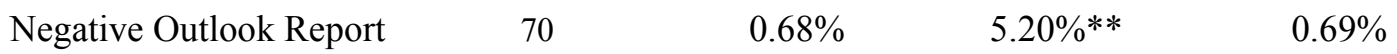

Positive / Stable

Outlook Report

61

$-0.20 \%$

$-1.92 \% *$

$-0.44 \% *$

Downgrade

57

$0.48 \%$

$3.60 \%$ *

$0.02 \%$ 
Table 3

The Table reports the mean change in the adjusted CDS spreads over the announcement period for the different rating actions and the different rating categories. The time intervals $[-10,-1],[-1,1]$ and $[1,10]$ refer to the pre-announcement period, the event day and the post-announcement period, respectively. "No. of Events" refers to the number of observations within each category. * and ** indicate that the adjusted CDS spread changes are different at the $5 \%$ and $1 \%$ confidence level, respectively.

\begin{tabular}{|c|c|c|c|c|c|}
\hline & & \multicolumn{4}{|c|}{ Announcement Period } \\
\hline & & $\begin{array}{l}\text { No. of } \\
\text { Events }\end{array}$ & {$[-10,-1]$} & {$[-1,1]$} & {$[1,10]$} \\
\hline \multirow{3}{*}{$\begin{array}{c}\text { Negative } \\
\text { Outlook Report }\end{array}$} & $\mathrm{Aaa} / \mathrm{Aa}$ & 19 & $0.2 \%$ & $8.22 \% *$ & $0.25 \%$ \\
\hline & A & 30 & $1.27 \% *$ & $3.50 \% *$ & $0.84 \%$ \\
\hline & Baa & 21 & $0.21 \%$ & $4.89 \%$ & $0.87 \%$ \\
\hline Positive / & $\mathrm{Aaa} / \mathrm{Aa}$ & 19 & $-0.26 \%$ & $-1.44 \%$ & $-0.26 \%$ \\
\hline Stable & A & 22 & $0.06 \%$ & $-1.78 \% *$ & $-0.25 \%$ \\
\hline \multirow[t]{2}{*}{ Outlook Report } & $\mathrm{Baa}$ & 20 & $-0.74 \%$ & $-1.83 \%$ & $-0.62 \% *$ \\
\hline & $\mathrm{Aaa} / \mathrm{Aa}$ & 8 & $0.28 \%$ & $2.30 \%$ & $0.28 \%$ \\
\hline \multirow[t]{2}{*}{ Downgrade } & A & 23 & $-0.04 \%$ & $2.02 \%$ & $0.01 \%$ \\
\hline & $\mathrm{Baa}$ & 26 & $0.76 \%$ & $5.39 \% *$ & $-0.06 \%$ \\
\hline
\end{tabular}




\section{Table 4}

The Table reports the difference in the mean change in the adjusted CDS spreads on the announcement day for all downgrades and the particular events. "2-notch downgrade" refers to the effect of a 2-notch downgrade compared to a 1-notch downgrade. "Category Dismissal" refers to the effect of a downgrade that results in a shift from one rating category in another. "Preceding Negative Outlook Report" refers to the effect of a downgrade of a company that was preceded by a negative outlook report during the control period. * and ** indicate that the adjusted CDS spread changes are different at the $5 \%$ and $1 \%$ confidence level, respectively.

Announcement Period

$\left.\left.\begin{array}{l}\text { No. of } \\ \text { Events }\end{array}\right]-1,1\right]$

2-notch Downgrade

Category Dismissal

26

$4.01 \% *$

Preceding Negative

Outlook Report 